\title{
Die vraag na 'verstaan' in die Christologie van D Bonhoeffer
}

\author{
JH Koekemoer
}

\section{Abstract \\ 'Understanding' in the Christology of D Bonhoeffer}

There has been a change in the approach to hermeneutics, with the result that it is no longer considered merely auxiliary to exegesis, but is seen as a basic science, the central problem of the so-called new understanding of Scriptures. In the study of Dogmatics this opens new visions. In this regard Bonhoeffer asked certain questions, of which some are still important today. Characteristic of Bonhoeffer is that man, who has 'come of age' and is 'a-religious', is of decisive importance in the construction of a Christology. To 'save' the 'Gospel' in a world that has 'come of age', a new understanding of Scriptures is necessary, and this must be done in an a-religious way. The only question is whether he did not lose both the uniqueness of the Christian revelation and faith and the reality that is central to Christianity.

\section{INLEIDENDE OPMERKINGS}

By die emeritaatsaanvaarding van Prof BJ Engelbrecht bring ek graag hulde aan 'n hoogleraar wat met wetenskaplike noukeurigheid en ' $n$ sistematiese denkpatroon die Dogmatiek binne die Teologiese opset van die Nederduitsch Hervormde Kerk van Afrika gevestig en beoefen het.

Binne die raamwerk van sy beoefening van die Dogmatiek is daar onder andere die leerstuk van die Christologie wat sy aandag steeds besig gehou het. Soveel so dat hy by meer as een geleentheid die uitspraak gemaak het dat ' $n$ dwaling in die Christologie spoedig lei tot ' $n$ dwaling in die ander loci van die Dogmatiek. Dit is daarom nie verbasend nie, dat hy hom steeds op hoogte gehou het met die ontwikkeling op die gebied van die Christologie.

In die Christologiese debat was $\mathrm{D}$ Bonhoeffer seker een van die persone wat vrae op die tafel geplaas het, waarmee teoloë op een of ander wyse tans nog worstel. Dit gebeur immers tans nog so dat die 
belangrikheid van Bonhoeffer telkens weer op die voorgrond tree. Verder is dit nogal insiggewend dat die Christologie ' $n$ belangrike aspek van Bonhoeffer se denke verteenwoordig.

Om enigsins ' $n$ geheelbeeld van die denke van hierdie Duitse geleerde te verkry, is nie maklik nie, omdat dit hom nie gegun was om sy gedagtes rustig in 'n studeerkamer uit te werk en neer te skryf nie, aangesien die Duitse Gestapo gedurig op sy spoor was. Hy is dan ook op betreklike jeugdige leeftyd, op 39-jarige ouderdom, in 'n konsentrasiekamp om die lewe gebring.

Vir die doel van hierdie studie sal gebruik gemaak word van 'n paar geskrifte, briewe uit die konsentrasiekamp en die lesings oor die Christologie wat hy van Mei tot Julie 1933 aan die Universiteit van Berlyn gegee het. Wat laasgenoemde betref, word gebruik gemaak van 'n rekonstruksie van sy lesings saamgestel deur Eberhard Bethge.

Die opskrif van die artikel dra die titel van die vraag na 'verstaan' in die Christologie van D Bonhoeffer. Daarom sal eers enkele opmerkings oor 'verstaan' en die faktore wat verstaan beinvloed, gemaak moet word. Dit is nodig omdat binne die denkpatroon van Bonhoeffer dit'n bepaalde invloed uitgeoefen het.

\section{DIE PROBLEEM VAN 'VERSTAAN' EN DIE FAKTORE WAT DIT BEÏNVLOED}

Die verandering in die gesigsveld van die teologiese hermeneutiek vanaf die beginsels van analise na die probleem van verstaan het vir die beoefening van die Dogmatiek nuwe visies geopen, maar tegelyk ook nuwe probleme na vore geroep. In 'n sekere sin kan die wending na $F$ Schleiermacher en W Dilthey teruggevoer word.

Dit het duidelik geword dat die blote toepassing van die kategorieë van logiese en stilistiese analise nie sonder meer daartoe lei dat die inhoud van 'n werk verstaan kan word nie.

Daar is ander oorwegings soos 'n lewende relasie tussen die interpreteerder en die wordingsproses van die werk wat aan die orde moet kom. Bultmann het ook ernstig aan die probleem van verstaan aandag gegee. Dit was vir hom in elke geval duidelik dat die hermeneutiek hom besig hou met die probleem van verstaan. Dit is die universele teorie omtrent verstaan. Dit vra na wat verstaan is en in die verlangde daarvan: waarop verstaan van toepassing is en waarop nie, wat vir verstaan in aanmerking kom en wat nie (Kuitert 1967: 41). 
Vir Bultmann was dit belangrik dat daar oor die kloof tussen hede en verlede op so ' $n$ wyse heen beweeg moet word dat die verlede iets aktueels word. Dit kan alleen indien erns gemaak word met die verstaansvraag. Bultmann se hantering van die vraag bring hom uiteindelik daartoe om die oplossing in sy eksistensiale interpretasie te sien. Hierdie oplossing van Bultmann bring wel sekere ooreenkomste asook verskille met Bonhoeffer na vore.

In Bonhoeffer se hele teologie is daar ' $n$ duidelike interesse na die eksistensiële in die geloof. Dit tree veral in sy geskrifte waar daar oor die navolging van Christus en oor die etiek gehandel word na vore. Vir hom het die Christelike boodskap in hierdie wêreld onverstaanbaar geword en juis daarom moet daar gesoek word na antwoorde sodat daar weer só gepreek kan word dat die moderne mens dit kan verstaan. Die vraag of Bonhoeffer en Bultmann mekaar reg verstaan het, word nie hier hanteer nie. Tog blyk dit interessant om daarop te let dat Bonhoeffer van oordeel was dat die groot vraag van hoe Jesus Christus die Heer van die religielose mens kan word, nie deur Bultmann se hermeneutiek hanteer word nie. Hy reken dat die ontmitologisering van Bultmann die religieuse interpretasie van die Bybel onaangetas gelaat het (Kuitert 1967: 83-84).

Hierdie beskouinge van Bonhoeffer het tot stand gekom omdat ander faktore ook ' $n$ rol gespeel het in sy oplossing van die verstaansprobleem. Hier kan veral gedink word aan die anti-metafisiese tendens in die teologie en sy eie beskouinge oor religie en die mondige mens.

\section{DIE PROSES VAN 'VERSTAAN' BY BONHOEFFER}

Wie enigsins Bonhoeffer se denke in dié verband wil probeer verstaan, sal erns moet maak van die begrippe 'mondigheid' en 'nie-religieus' in sy gedagtegang. Van Ruler (1972: 176) is van oordeel dat hy die mondigheid van die mens op verskillende stadia van die Europese geskiedenis waarneem. Die begrip word egter telkens anders geïnterpreteer. Aspekte wat hierin na vore tree, is die ontvoogding van die staat uit die heerskappy van die kerk, bepaalde ontdekkinge wat die mens ' $n$ gevoel van outonomie laat ontwikkel het en die Kantiaanse transendentalisme waarvolgens God kenteoreties nie 'n plek binne die menslike rasionele denke het nie.

Op grond van hierdie waarneming is dit vir Bonhoeffer 'n uitgemaakte saak dat die mens God nie meer as 'n voog nodig het nie. Die 
voortgesette mondigheid van die mens beteken dat God al verder uit die wêreld verdryf is. Die mens het geleer om alle vrae van belang te hanteer sonder om God as 'n werkhipotese te gebruik. Hierdie mondige mens neem afskeid van onmondigheid en in hierdie konteks beteken dit afskeid van die religie, die kerk en ook van 'God'. Vir die mens is daar nie enige omdraaimoontlikhede oor nie. Daar is alleen maar ' $n$ voortgang op die weg na vryheid.

Wanneer dít gestel is, sal uitgemaak moet word wat Bonhoeffer onder religie verstaan het. Die probleem hier is weer eens dat hyself dit nie baie duidelik omskryf het nie. Hy het wel die begrippe metafisika en innerlikheid met religie in verband gebring (Van Ruler 1972: 180). Daarom lyk dit ook korrek om te sê dat religie met die hiernamaals te make het, met die wêreld agter die aardse werklikheid. Die werklikheid word aangevul deur van 'God' in die argument gebruik te maak. God word gestel as die oplossing van die lewensvrae, die verwarring en onsekerheid waarin die mens homself bevind in die aangesig van die naderende dood.

Van Ruler (1972: 180) formuleer teen dié agtergrond dan ook tereg 'n sestal besware van Bonhoeffer teen religie:

- Religie het te make met die individuele mens en sy innerlikheid. So word dit geheel en al vergeestelik en kry dit 'n trek van 'onaardsheid'. So word nie erns gemaak met die wêreld en die sosiale lewensvorme daarvan nie.

- Hy het ernstige bedenkinge teen die metode van die religie, naamlik om die swakheid van die mens uit te buit. Die mens moet eers op sy knieë gaan voor jy met hom iets kan uitvoer.

- Religie lei altyd daartoe dat die mens sy eie verlosser word.

- Daar word op 'n te ondeurdagte wyse van die vroomheid van ander gepraat.

- Dit maak van die Christendom 'n verlossingsreligie, wat dit teen sy Ou-Testamentiese agtergrond gesien, nie is nie. Hier het hy dit veral teen die gedagte van die Hellenistiese misteriereligieë wat die mens se verlossing sien as 'n verlossing van die aarde, van die liggaam en selfs van die lewe. Vir hom ken die Bybel nie so 'n verlossing nie, maar is daar alleen sprake van die instuur van die mens in die geskiedenis in. Die mens bly geroepe tot 'n taak en verantwoordelikheid in die geskiedenis en nie tot religie nie. Daarom roep Jesus ook nie op tot religie nie 'maar tot 'n lewe (hier - en nou) en geloof (eksistensiële beslissing)' (Engelbrecht 1967: 18). 
- Die religie voer 'n mens terug tot agter die openbaringsteologie. In hierdie verband het hy aansluiting by Karl Barth gevind ten opsigte van sy beskouing dat Openbaring en geloof die teendeel van religie is en dat religie deur die Openbaring opgehef word. In dié verband tree daar ook ' $n$ verskil tussen Bonhoeffer en Barth na vore waarop gewys moet word.

Terwyl Barth religie sien as ' $n$ algemeen menslike verskynsel met die gevolg dat daar nie sprake kan wees van 'n wêreld sonder religie nie, interpreteer Bonhoeffer religie histories en kan religie derhalwe verdwyn en hét dit inderdaad ook vir die mondige mens verdwyn, sodat daar gepraat kan word van 'n mens wat sonder religie is. Omdat die einde van religie in die geskiedenis van die mens is, beskou Bonhoeffer dit as die belangrikste gebeurtenis van die twintigste eeu. Dit bring nou inderdaad die vraag na vore of die einde van die religie ook die einde van die Christendom beteken.

Hierdie vraag sou positief beantwoord moes word indien Bonhoeffer die Christendom as ' $n$ religie sou beskou. Op hierdie punt argumenteer hy dat die kerk in die verlede die Bybel wel religieus geïnterpreteer het. Daarom beteken die einde van religie ten minste die einde van die tradisionele Christendom. Bonhoeffer (1970) pleit daarom vir' $n$ interpretasie van die Bybel in ' $n$ nie-religieuse idioom. So alleen kan daar vir die mondige mens van verstaan van die Bybelse boodskap sprake wees.

\section{DIE CHRISTOLOGIE BY BONHOEFFER}

In die lig van die voorafgaande moet nou oorgegaan word om die vraag na die moontlikheid van ' $n$ Christologie vir die mondige mens by Bonhoeffer aan die orde te stel. Kan Christus werklik nog die Heer wees van die mondige mens, en indien wel hoe kan $\mathrm{Hy}$ dit word?

In sy lesings oor die Christologie (Bonhoeffer 1966) kom dié saak onder andere aan die orde: In hierdie verband is daar veral twee sake wat in gedagte gehou moet word:

- Behalwe dat op 'n nie-religieuse wyse geïnterpreteer moet word om verstaan moontlik te maak, is die vraag: 'Hoe is dit moontlik om die geinkarneerde voor te stel?', 'n ontoelaatbare vraag. Al vraag wat beantwoord moet word is: 'Wie is hy?'.

- Verder is Christus alleen werklik in relasie tot my. Dit gaan nie in die eerste plek om die kennis van die persoon of werk van Jesus Christus 
nie, maar om sy betekenis 'pro me'.

Jesus Christus was nie iemand wat oorklee was met menslike eienskappe nie. Hy het sy eie menslike hipostasis gehad. En van hierdie mens kan ons dan sê: 'Hy is God vir ons'. Dit beteken nie dat ons van Jesus Christus sê dat hy 'n menslike natuur en 'n goddelike natuur gehad het nie. Met die uitspraak: 'hierdie mens is God', wil ons alleen sê dat die hele mens Jesus as God vir ons gekwalifiseer word.

Jesus Christus is eenmaal nie God in 'n goddelike ousia nie, hy is God in die geloof. Daar is nie iets soos 'n goddelike wese nie. In die Christologie kyk ons na die historiese mens Jesus en sê van hom ' $\mathrm{Hy}$ is God' (Bonhoeffer 1966: 110). Dit gaan verder in die Christologie nie om 'n twee-nature leer nie. Dit gaan oor die manier waarop God as mens eksisteer. Die vraag is nie 'Hoe kan God die vernederde mens wees nie', maar 'wie is die vernederde God-mens?' In die vernedering het Christus die wêreld van sonde en dood vrywillig en incognito betree. Hy het nie met vertoon as God-mens gekom nie, maar incognito gegaan as bedelaar tussen bedelaars, as uitgeworpene onder uitgeworpenes, as sterwende onder sterwendes (Bonhoeffer 1966: 110).

Ook die vernedering moet derhalwe pro nobis verstaan word. So is Christus in vryheid vir ons. So moet gelowiges dan ook incognito in vryheid in die wêreld leef vir ander mense. Soos by Jesus kan dit vir gelowiges ook lyding impliseer. Want as die Bybel sê dat die volk van God op hierdie aarde leef op weg na die ryk van geregtigheid en dat so ' $n$ lewe 'n lewe in die geloof is, dan ontmoet die een wat so leef op sý weg ook lyding. Jesus het immers ter wille van die Ryk en geregtigheid aan die kruis gesterf en $\mathrm{Hy}$ word elke dag in die minste van sy broers gekruisig (Bonhoeffer 1970: 413).

In die lig hiervan is geloof vir die mondige mens 'n eksistensiële beslissing en 'n lewe uit die geloof, navolging van Jesus. In hierdie bestaan vir andere word die transendensie beleef. So is ons verhouding tot God dan nie 'n religieuse verhouding nie, maar beteken dit eerder 'n nuwe lewe wat op ander mense gerig is, om op dié wyse deel te neem aan die bestaan van Jesus. Omdat Jesus plaasbekledend geleef het, dit beteken geleef het as een wat in sy persoon die 'ek' van alle mense opgeneem en gedra het, is alle menslike lewe bestem tot plaasbekledende lewe.

Daarom sal die kerk ook dan pas kerk wees as dit daar is 'vir andere'. Dit sal moet begin om sy besittings te verkoop en die geld 
aan die armes uit te deel. So sal dit aan die mense kan voorhou wat 'n lewe met Jesus beteken (Bonhoeffer 1970: 415). Bonhoeffer maak baie van die Paasfees. Maar hy verstaan ook dit anders. 'n Opstandingsgeloof beteken nie ' $n$ mitiese verstaan van die opstanding as ' $n$ opstanding in ' $n$ 'wêreld daarbo' nie. Dit beteken weer dat die mens in die wêreld ingestuur word om incognito deel te hê aan die lyding van God in die wêreld en om só op weg te wees na die Ryk en die geregtigheid.

\section{ENKELE KRITIESE OPMERKINGS}

Dit is duidelik dat dit nie so 'n eenvoudige saak is om Bonhoeffer te verstaan nie. Die fragmentariese wyse waarop sy gedagtes oorgelewer is en die feit dat hyself nie 'n volledig uitgewerkte Christologie daargestel het nie, bemoeilik ' $n$ interpretasie geweldig baie. Dit open verder die weg vir 'n verskeidenheid interpretasiemoontlikhede en vergroot ook die moontlikheid van verkeerde interpretasies.

Tog moet gestel word dat een saak bo verdenking staan. Dit is naamlik die erns wat Bonhoeffer openbaar het om die Bybelse inhoud vir die mondige mens verstaanbaar te maak. 'n Probleem in dié verband is egter dat die 'mondige' en 'nie-religieuse' mens van deurslaggewende betekenis geword het vir sy verstaan van die evangelie. Dit beteken dat hy gedurig geworstel het met die vraag hoe die kerugma die mens kan bereik. In die taal van Van Ruler (1972: 172), maak dit hom 'n 'vat vol tegenstrijdigheden' omdat hy die volmag van die prediking beide in die 'openbaring' en in die kennis en moderne lewensgevoel van die mens wil veranker.

'n Mens kry egter die indruk dat die moderne mens so deurslaggewend in sy verstaansproses word, dat die Christologie eintlik in ' $n$ antropologie verander. Verder toon sy denke sterk piëtistiese trekke en uiteindelik gaan dit by hom alleen om medemenslikheid sodat die geloof niks anders is nie as 'n navolging van Jesus van Nasaret nie.

Sy kritiek teen Bultmann as sou hy die mitologie wegverklaar het en nie geïnterpreteer het nie, hou nie werklik stand nie. Inteendeel, daar kan ernstige bedenkinge uitgespreek word teen Bonhoeffer se hantering van die mitologie. Sy hele inkleding van die Christologie as ' $n$ Christus pro me bring die selfstandigheid van Christus in gedrang en bring hom ook in teenstelling met die leer van die an-en enhipostasis 
van Chalcedon. In plaas daarvan dat ons as skepsel alleen op Christus aangewys is, wil dit voorkom of Christus op ons aangewys is.

'n Mens sou ook kon argumenteer dat Bonhoeffer se nie-religieuse interpretasie van die Bybel logies onhoudbaar is, want met die nuwe metodes en vorme van interpretasie waarmee hy hom besig hou, stel hy 'n nuwe program daar waarvolgens die Bybel geïnterpreteer moet word. So tree 'n nuwe religie na vore en val hy in 'n strik waaruit hy juis wou wegkom.

Dit bly egter belangrik om kennis te neem van sy worsteling met die verstaansvraag van die mondige mens ten opsigte van die evangelie. Die beantwoording van die vraag bly immers vir die kerk van deurslaggewende betekenis.

\section{Literatuurverwysings}

BONHOEFFER, D 1966. Christology. London: Collins.

BONHOEFFER, D 1968. Navolging. Amsterdam: Ten Have.

BONHOEFFER, D 1970. Widerstand and Ergebung. München: Kaiser.

ENGELBRECHT, BJ [1967]. Hedendaagse krisispunte in die Teologie. HTS 23/1, 5-23.

KUITERT, HM 1967. De realiteit van het geloof. Kampen: Kok.

SPERNA WEILAND, J 1967. Oriëntatie. Baarn: Het wêreldvenster.

VAN RULER, AA 1972. Theologisch werk, Deel V. Nijkerk: Callenbach. 